\title{
Production of Heparin Binding Epidermal Growth Factor-like Growth Factor in the Early Phase of Regeneration After Acute Renal Injury Isolation and Localization of Bioactive Molecules
}

\author{
Masahiro Sakai, ${ }^{*}$ Ming-zhi Zhang, ${ }^{\star}$ Toshio Homma, ${ }^{\star}$ Brett Garrick, ${ }^{\ddagger}$ Judith A. Abraham, ${ }^{\ddagger}$ J.A. McKanna, ${ }^{*}$ \\ and Raymond C. Harris ${ }^{\star \S}$ \\ *Department of Medicine and Cell Biology, Vanderbilt University School of Medicine, Nashville, Tennessee 37232; ${ }^{\ddagger}$ Scios Inc., Mountain \\ View, California 94043; and ${ }^{\S}$ Department of Veterans Affairs Medical Center, Nashville, Tennessee 37232
}

\begin{abstract}
We have recently reported that heparin-binding epidermal growth factor-like growth factor (HB-EGF) mRNA is induced in the rat kidney after acute ischemic injury. The present studies were designed to investigate whether bioactive HB-EGF protein is also produced in response to renal injury induced by either ischemia/reperfusion or aminoglycosides. Heparin-binding proteins were purified from kidney homogenates by heparin affinity column chromatography using elution with a $0.2-2.0 \mathrm{M}$ gradient of $\mathrm{NaCl}$. A single peak of proteins that eluted at $1.0-1.2 \mathrm{M} \mathrm{NaCl}$ was detected in the postischemic kidney within $6 \mathrm{~h}$ of injury. This eluate fraction stimulated DNA synthesis in quiescent Balb/c3T3, RIE, and NRK-52E cell lines, all of which are responsive to the epidermal growth factor family of mitogenic proteins. The EGF receptor of A431 cells was also tyrosine phosphorylated by this eluate peak. Furthermore, immunoblotting with a polyclonal antibody against rat HBEGF indicated that the eluate peak contained immunoreactive proteins of 22 and $29 \mathrm{kD}$ mol wt, consistent with the reported sizes of the secreted form and membrane anchored form of HB-EGF, respectively. Immunohistochemical studies revealed that HB-EGF was produced predominantly in distal tubules in kidneys injured either by ischemia/reperfusion or aminoglycoside administration. We also found that during metanephric development immunoreactive HB-EGF was detected in the ureteric bud as early as E14.5 and persisted in structures arising from the ureteric bud throughout embryogenesis. These results suggest that in response to acute injury, HB-EGF is produced predominantly in distal tubules and that endogenous HB-EGF may be an important growth factor involved in renal epithelial cell repair, proliferation, and regeneration in the early stages of recovery after acute renal injury, as well as in nephrogenesis. (J. Clin. Invest. 1997. 99:2128-2138.) Key words: heparin-binding epidermal growth factor-like growth factor $\bullet$ acute renal failure $\bullet$ nephrogenesis $\bullet$ distal tubule $\cdot$ renal regeneration
\end{abstract}

\footnotetext{
Address correspondence to Raymond C. Harris, Division of Nephrology, Department of Medicine, S-3223 Medical Center North, Vanderbilt University School of Medicine, Nashville, TN 37232. Phone: 615343-0030; FAX: 615-343-7156; E-mail: ray.harris@mcmail.vanderbilt.edu

Received for publication 17 September 1996 and accepted in revised form 7 February 1997.
}

The Journal of Clinical Investigation

Volume 99, Number 9, May 1997, 2128-2138

\section{Introduction}

The mammalian kidney is susceptible to injury by ischemia/ reperfusion and nephrotoxins, and regeneration after injury is characterized by hyperplasia and recovery of the epithelial cell lining of the tubules (1). When the intensity and/or duration of injury is severe, the tubular cells either undergo necrosis or detach from the basement membrane. However, in nephron segments where the insult is limited, cells may become transiently dysfunctional but will ultimately survive (2). Recent studies have also indicated that a subpopulation of cells destined to undergo programmed cell death can be identified in acute renal injury (3-5). Therefore, cellular proliferation and differentiation are required to maintain structural integrity and to restore function (2). Recent studies have indicated that in response to acute injury, epithelial cells dedifferentiate and become capable of proliferating, and all renal epithelial cells appear to retain the capacity to serve as progenitor cells (6). Cell-cell and cell-matrix interactions are also altered in response to acute injury $(7,8)$.

Locally produced growth factors may mediate proliferation and differentiation during renal regeneration after acute renal injury (2), and exogenous administration of these growth factors accelerates recovery of renal function. These growth factors include epidermal growth factor, hepatocyte growth factor (HGF), ${ }_{1}^{1}$ and insulin-like growth factor-I (9-13). A number of studies have investigated the potential role of EGF and/or the EGF family of growth factors in renal injury $(9-11,14)$. EGF production in the normal adult mammalian kidney has been localized to the thick ascending limb/distal convoluted tubule (15). After ischemia, cis-platinum, or aminoglycoside-induced injury or acute ureteral obstruction, both preproEGF mRNA levels and urinary EGF excretion decrease and remain significantly depressed for up to $7 \mathrm{~d}(16,17)$, whereas EGF receptor (EGF-R) binding increases $(16,18)$.

In addition, previous studies have suggested a role for EGF and EGF family members in renal development (19-21). Similar to the kidney recovering from acute injury, EGF-R binding and receptor tyrosine phosphorylation increase during days 16-21 of rodent and murine gestation (22). However, no study has been able to prove conclusively that either EGF or transforming growth factor $\alpha$ are involved in metanephric development $(19,23-26)$.

Several growth factors have been identified that signal through the EGF-R, the so-called EGF superfamily of growth

1. Abbreviations used in this paper: EGF-R, epidermal growth factor receptor; FGF, fibroblast growth factor; FPLC, fast protein liquid chromatography; HB-EGF, heparin-binding epidermal growth factor-like growth factor; HGF, hepatocyte growth factor; TALH, thick ascending limb of Henle. 
factors. Members include TGF $\alpha$ (27), amphiregulin (28), and betacellulin (29). Heparin-binding EGF-like growth factor (HB-EGF), a 20-22-kD glycoprotein originally purified from conditioned media of a macrophage-like cell line, U937, is another member of the EGF family (30). We have previously reported that HB-EGF mRNA was significantly increased in rat kidney after ischemia/reperfusion- and mercuric chlorideinduced acute injury (31). This induction occurred earlier than reported for other growth factors such as HGF (32), acidic fibroblast growth factor (33), and IGF-I (34). Recombinant HBEGF was also found to be mitogenic for renal epithelial cells (31). In the present studies, we investigated whether bioactive HB-EGF was produced in the injured kidney and identified which cells were responsible for its production.

\section{Methods}

Experimental model. Ischemic renal injury was produced in male Sprague-Dawley rats weighing 150-200 g. Unilateral renal ischemia was induced by surgical clamping of the left renal artery for $50 \mathrm{~min}$ as previously described (35). After removal of the clamp to allow reperfusion for the indicated periods, rats were killed and kidneys were removed for analysis. The contralateral kidney was used for the appropriate time control. Aminoglycoside nephropathy was induced by subcutaneous injection of either 200 or $400 \mathrm{mg} / \mathrm{kg}$ per d gentamicin sulfate every $8 \mathrm{~h}$ for $2 \mathrm{~d}$ (36). An equal volume of saline was injected into control animals.

Purification of heparin binding proteins. Heparin-binding proteins were purified by heparin affinity chromatography as previously described by Higashiyama et al. (30), with some modifications. Rats were killed by cervical dislocation and the kidneys were immediately homogenized with a Potter homogenizer in ice cold buffer $(150 \mathrm{mM}$ $\mathrm{KCl}, 10 \mathrm{mM}$ Tris, $\mathrm{pH}$ 7.4, $1 \mathrm{mM}$ EDTA, $1 \%$ Triton X-100, $1 \mathrm{mM}$ phenylmethylsulfonyl fluoride, $10 \mu \mathrm{g} / \mathrm{ml}$ aprotinin, $10 \mathrm{mM}$ benzamidine). After centrifugation at $10,000 \mathrm{~g}$ for $30 \mathrm{~min}$ to remove insoluble materials, supernatants were centrifuged at $100,000 \mathrm{~g}$ for $60 \mathrm{~min}$. The resulting supernatant was dialyzed against equilibration buffer $(0.2 \mathrm{M}$ $\mathrm{NaCl}, 10 \mathrm{mM}$ Tris, $\mathrm{pH}$ 7.4), and applied to a heparin-sepharose column preequilibrated with the same buffer. After extensive washing, the heparin-binding proteins were batch eluted with elution buffer (2.0 M NaCl, $10 \mathrm{mM}$ Tris, $\mathrm{pH}$ 7.4). The eluate was dialyzed against equilibration buffer and fractionated with a heparin-TSK column (7.5 $\mathrm{cm} \times 8 \mathrm{~mm}$; TosoHAAS, Philadelphia, PA) using a fast protein liquid chromatography (FPLC) system (Waters 600E system; Millipore Corp., Bedford, MA). Heparin-binding proteins were eluted with a $0.2-2.0 \mathrm{M}$ linear $\mathrm{NaCl}$ gradient in $10 \mathrm{mM}$ Tris- $\mathrm{Cl}, \mathrm{pH} 7.4$, at $1 \mathrm{ml} / \mathrm{min}$ over $40 \mathrm{~min}$. The eluted proteins were detected by an ultraviolet (UV) monitor at $280 \mathrm{~nm}$. Each fraction was collected in a volume of 1 $\mathrm{ml}$ and tested for biological activity.

Mitogenic activity of the fractions. Three cell lines, Balb/c3T3, RIE-1 (37), and NRK-52E (38) were used for mitogenic assays. Earlier studies have indicated that these cell lines are responsive to $\operatorname{EGF}(30,31$, 39). The mitogenic activity was determined by ${ }^{3} \mathrm{H}$-thymidine incorporation. Cells were cultured in 24-well culture plates in Dulbecco's modified Eagle's medium (Sigma Chemical Co., St. Louis, MO) supplemented with $10 \%$ fetal calf serum (Hyclone, Logan, UT). After cells reached confluence, the medium in each well was changed to 500 $\mu \mathrm{l}$ of serum free medium for 2-3 d. Cells were then incubated with 5 $\mu l$ of eluate fractions from heparin-TSK column chromatography and labeled with $1 \mu \mathrm{Ci} /$ well of ${ }^{3} \mathrm{H}$-thymidine (Amersham Corp., Arlington Heights, IL) during 16-20 h of incubation. In each culture plate, $60 \mathrm{nM}$ of epidermal growth factor (Collaborative Research, Inc., Lexington, MA) was used as a positive control. Cells were washed with cold phosphate-buffered saline and precipitated with $10 \%$ trichloroacetic acid for $30 \mathrm{~min}$ on ice. Acid-precipitable material was dissolved in $0.5 \% \mathrm{SDS} / 0.2 \mathrm{~N} \mathrm{NaOH}$ and radioactivity was determined by scin- tillation spectrometry. Mitogenic activity was represented as the ratio of ${ }^{3} \mathrm{H}$-thymidine incorporation compared with that of $60 \mathrm{nM}$ EGF.

Immunoprecipitation of EGF receptor and determination of tyrosine phosphorylation. A431 cells, which overexpress EGF-R (40), were incubated with either saline or mitogenic fractions on ice for $10 \mathrm{~min}$ in kinase buffer (20 mM Hepes, $1 \mathrm{mM} \mathrm{MnCl}, 1 \mathrm{mM}$ orthovanadate, $1 \mathrm{mM}$ phenylmethylsulfonyl fluoride, $10 \mu \mathrm{g} / \mathrm{ml}$ aprotinin, $\mathrm{pH}$ 7.4) as previously described (41), lysed with RIPA buffer (150 mM $\mathrm{NaCl}, 1.0 \%$ Nonidet P-40, $0.5 \%$ sodium deoxycholate, $0.1 \%$ SDS, 50 $\mathrm{mM}$ Tris, $\mathrm{pH} 8.0$ ), and immunoprecipitated at $4^{\circ} \mathrm{C}$ with sheep antihuman EGF receptor polyclonal antibody (Upstate Biotechnology Inc., Lake Placid, NY). Immune complexes were collected by Pansorbin cells (Calbiochem Corp., San Diego, CA) after incubation with rabbit anti-sheep IgG antibody (Pierce, Rockford, IL) and washed extensively. The resulting precipitated proteins were denatured with Laemmli buffer and fractionated on 6\% SDS-polyacrylamide gels under reducing conditions. The proteins were electrophoretically transferred to polyvinylidene fluoride membranes (Immobilon P; Millipore Corp.). After blocking with 3\% BSA in Tris-buffered saline, the blots were probed with an antiphosphotyrosine monoclonal antibody (PY20; ICN Biomedicals Inc., Costa Mesa, CA), followed by a biotinylated anti-mouse antibody (Pierce), and then were visualized by a horseradish peroxidase detection system (Pierce).

Immunodetection of HB-EGF. To detect immunoreactive HBEGF, goat 19 antibody against recombinant rat HB-EGF was used. This antibody was generated by immunizing goats with recombinant rat HB-EGF and has been shown to recognize rat HB-EGF by Western blot (42). The mitogenic fractions from the kidney homogenates after ischemic injury were concentrated, fractionated on $15 \%$ SDSpolyacrylamide gels under reducing conditions, and transferred to polyvinylidene fluoride membranes. After blocking with phosphatebuffered saline containing $5 \%$ nonfat milk, the blots were incubated with the goat anti-rat HB-EGF antibody and visualized by an enhanced chemiluminescence system (ECL; Amersham Corp.).

RNA isolation and Northern analysis. Total RNA was isolated from either total kidney homogenates or from visually dissected cortex, outer medulla, and inner medulla. RNA was purified by the acid guanidinium thiocyanate-phenol-chloroform method (43) and subjected to Northern blot analysis as previously described (44). $15 \mu \mathrm{g}$ of RNA/lane was subjected to electrophoresis in formaldehyde-denatured $1 \%$ agarose, transferred to nylon membranes (Schleicher \& Schuell, Inc., Keene, NH) and fixed to the membrane by exposing to UV radiation. After prehybridization, blots were hybridized with ${ }^{32} \mathrm{P}-$ labeled cDNA probes. After washing at high stringency, the membranes were exposed at $-70^{\circ} \mathrm{C}$ to film (Amersham Corp.) with an intensifying screen. Probes used were a $1.5-\mathrm{kb}$ fragment of rat HB-EGF cDNA and a $2.3-\mathrm{kb}$ fragment of rat EGF-R cDNA. Blots were stripped and reprobed with a human GAPDH cDNA probe and the HB-EGF and EGF-R mRNA levels detected were normalized to GAPDH expression.

Immunohistochemical localization of HB-EGF. Rabbit anti-human HB-EGF polyclonal antibody 2998 was used for immunohistochemical detection of HB-EGF in rat kidney. In preliminary studies, fixation with FPAS (formalin/sodium periodate/acetic acid) (35) was found most effective for immunohistochemistry with this antibody. After various periods of reperfusion, kidneys were perfused with saline, fixed with FPAS and embedded in paraffin. Immunoreactive HB-EGF was visualized by ABC-elite Vectastain reagents (Vector Laboratories, Inc., Burlingame, CA). Similarly, rat embryos were fixed with FPAS at the indicated gestational age. To determine specificity of immunoreactivity, anti-HB-EGF antibody was preabsorbed with recombinant human HB-EGF (R\&D Systems, Inc., Minneapolis, $\mathrm{MN}$ ) before immunodetection.

\section{Results}

Purification of HB-EGF from the rat kidney after ischemia/reperfusion injury. HB-EGF was originally purified from the 


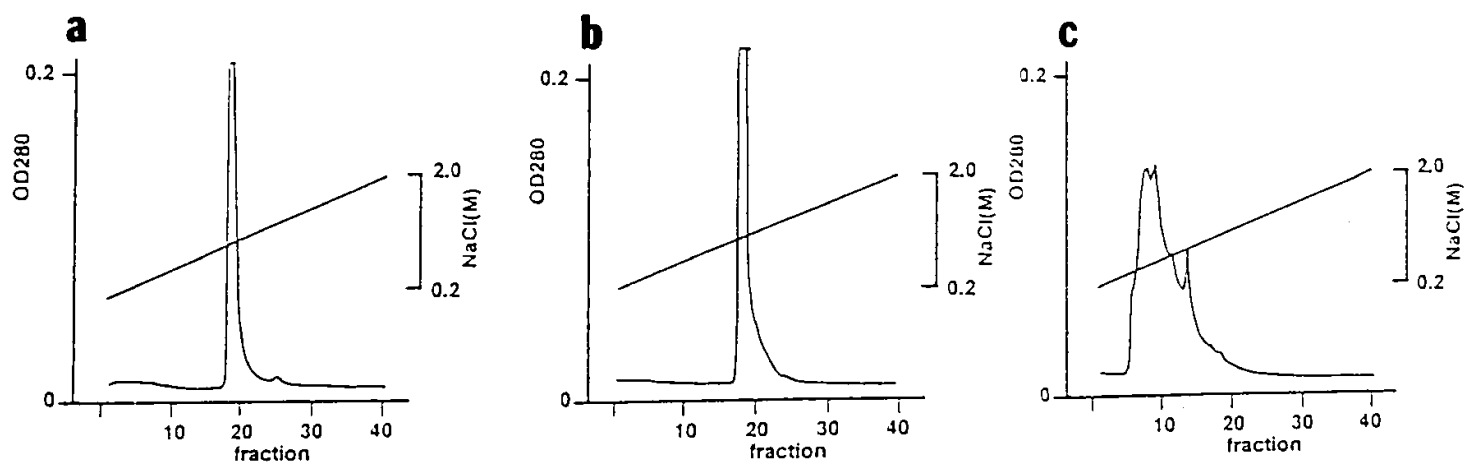

B
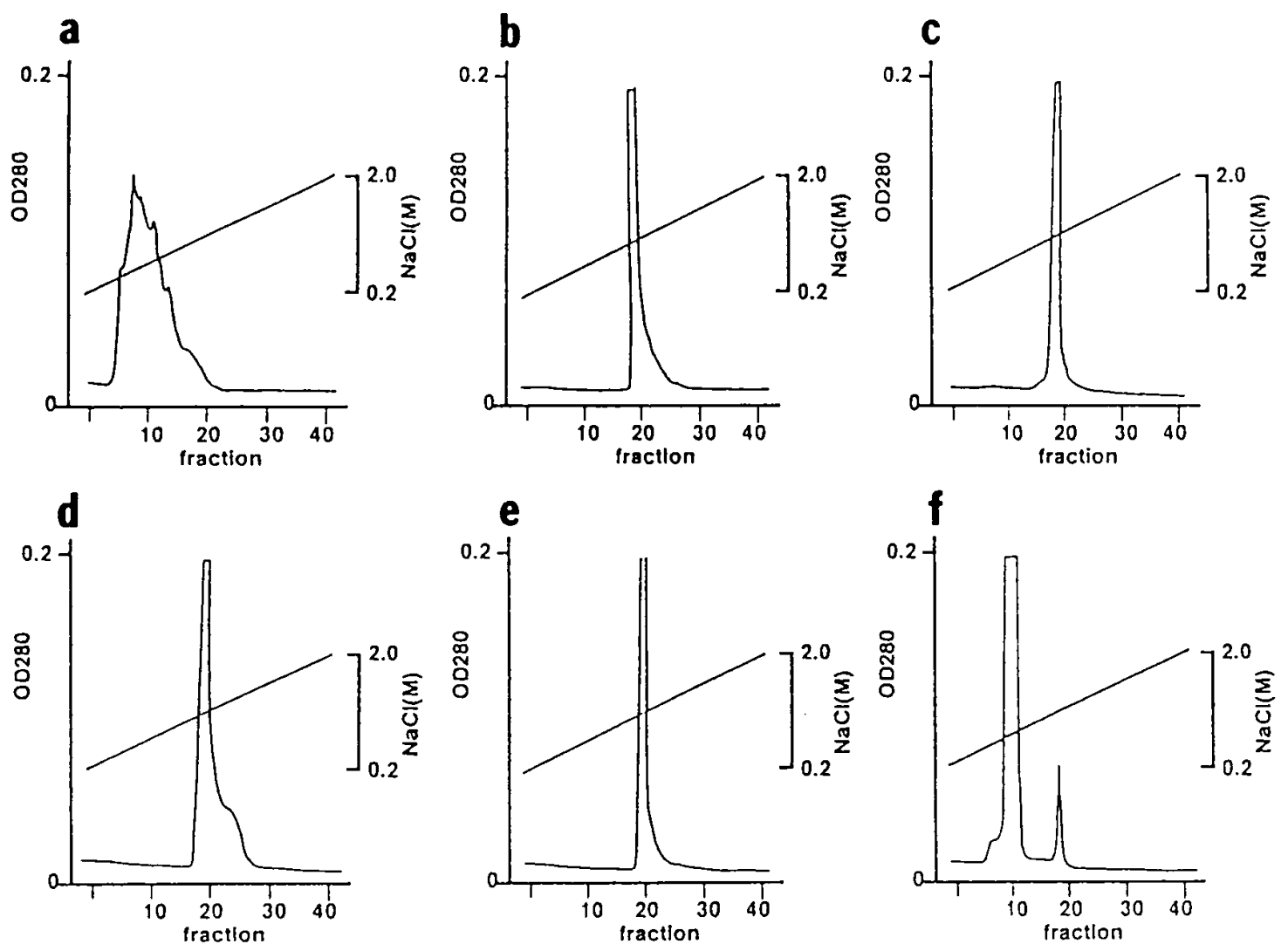

Figure 1. Isolation of heparin-binding proteins by heparin-affinity column chromatography from rat kidney and conditioned medium of U937 cells. (A) Heparin-binding proteins were collected by heparin-Sepharose columns from either conditioned medium prepared from U937 cells $(a)$ or homogenates of $6 \mathrm{~h}$ postischemic $(b)$, or $6 \mathrm{~h}$ contralateral rat kidney $(c)$, and further fractionated by heparin-TSK FPLC as described in Methods. Heparin-binding proteins were eluted with $0.2-2.0 \mathrm{M}$ gradients of $\mathrm{NaCl}$ and absorbance at $280 \mathrm{~nm}$ was recorded. $(B)$ Postischemic kidneys were harvested and homogenized after various periods of reperfusion and subjected to purification of heparin-binding proteins by heparin-affinity column chromatography. The heparin-TSK elution pattern of each sample is presented. $a, 3 \mathrm{~h} ; b, 6 \mathrm{~h} ; c, 12 \mathrm{~h} ; d, 24 \mathrm{~h} ; e, 72 \mathrm{~h} ; f, 7 \mathrm{~d}$.

conditioned medium of U937 cells by heparin affinity chromatography (30). To investigate whether bioactive HB-EGF increased in the rat kidney in response to acute injury, rats were subjected to 50-min unilateral renal artery clamp, followed by various times of reperfusion. Kidney homogenates were subjected to heparin affinity column chromatography and heparin-binding proteins were fractionated by FPLC using elution with a $0.2 \mathrm{M}-2.0 \mathrm{M} \mathrm{NaCl}$ gradient $(n=3-8)$. In contralateral kidneys, a broad low peak of absorbency at $280 \mathrm{~nm}$ was eluted with $0.4-0.8 \mathrm{M} \mathrm{NaCl}$ (Fig. $1 A, c$ ). In contrast, from the 6-h postischemic kidney, a large single peak was eluted with $1.0-1.2 \mathrm{M} \mathrm{NaCl}$ (Fig. $1 A, b$ ). This elution pattern is identical to that obtained with medium conditioned by U937 cells (Fig. $1 \mathrm{~A}, a$ ). The time course from the postischemic kidney is shown in Fig. 1 B. A similar peak eluting with $1.0-1.2 \mathrm{M} \mathrm{NaCl}$ was observed at $6,12,24$, and $72 \mathrm{~h}$ after ischemia but not at $3 \mathrm{~h}$ or $7 \mathrm{~d}$.

To characterize the bioactivity of the heparin-binding pro- 

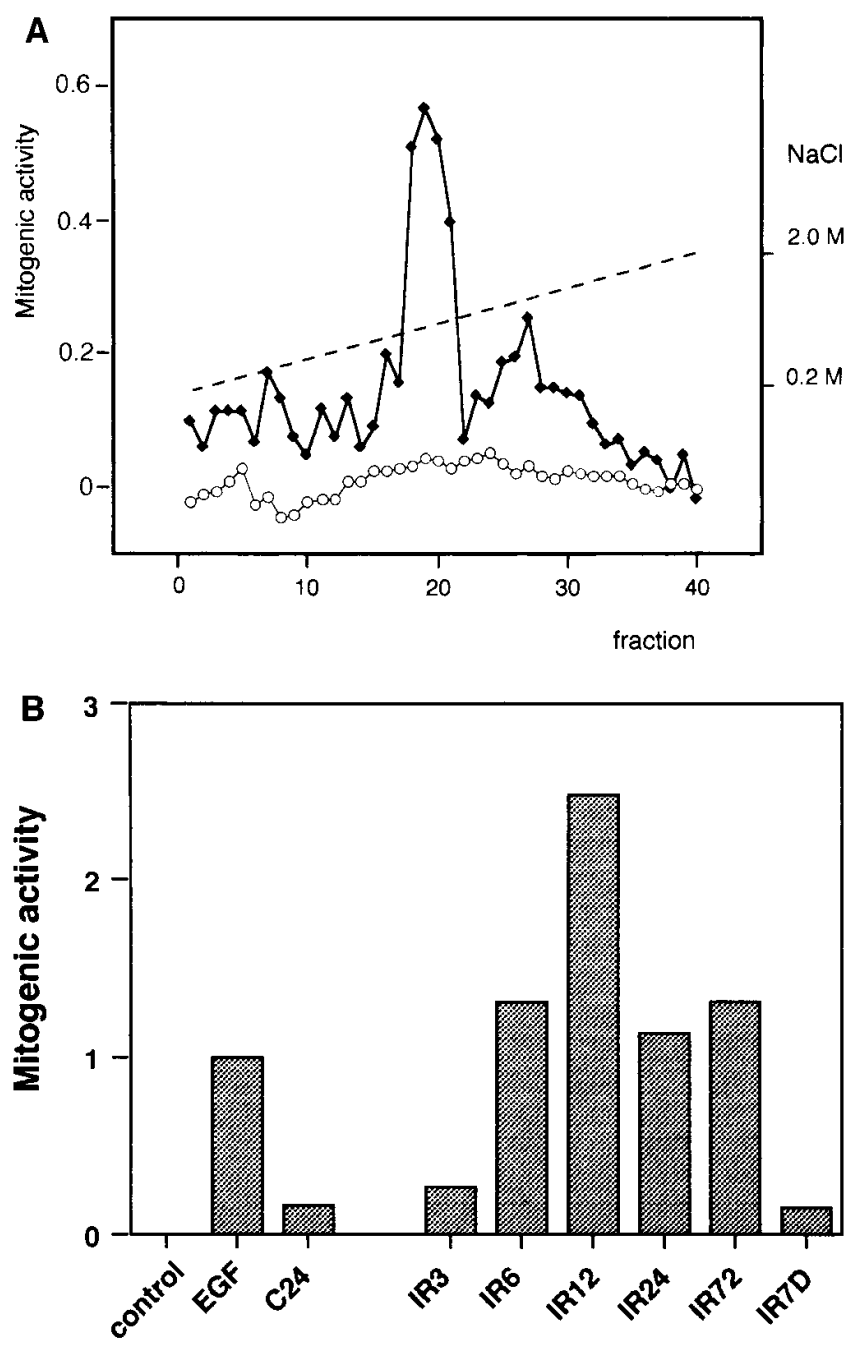

Figure 2. Mitogenic activity of the eluted fractions of heparin-TSK FPLC columns. The eluted fractions were tested for mitogenic activity. Quiescent cells were incubated either with the eluate fractions from heparin-TSK FPLC columns at a final 1:100 dilution or with 60 $\mathrm{nM}$ of EGF, and ${ }^{3} \mathrm{H}$-thymidine incorporation was determined as described in Methods. Mitogenic activities of the eluate fractions are presented as the ratio to that induced by $60 \mathrm{nM}$ EGF. $(A)$ Quiescent NRK-52E cells were incubated with eluate fractions from either $24 \mathrm{~h}$ postischemic kidney or contralateral kidney. $\diamond$, Postischemic kidney; $\mathrm{O}$, contralateral kidney. ${ }^{3} \mathrm{H}$-Thymidine incorporation by $60 \mathrm{nM}$ EGF, 19,159 cpm; control, 3,345 cpm. (B) Fraction 19 was prepared from unilateral postischemic kidney after indicated times of perfusion and examined for mitogenic activity for Balb/c3T3 cells. C24, contralateral kidney $24 \mathrm{~h}$ after reperfusion; IR, ischemic/reperfused kidney. The times indicate hours after reperfusion. ${ }^{3} \mathrm{H}$-Thymidine incorporation by $60 \mathrm{nM}$ EGF, 4,883 $\pm 1,992 \mathrm{cpm}$; control, 2,510 $\pm 1,211 \mathrm{cpm}$.

teins eluted with $1.0-1.2 \mathrm{M} \mathrm{NaCl}$, the mitogenic activity of each fraction collected during heparin-TSK FPLC chromatography was examined. The target cells used in these experiments have all previously been shown to be responsive to EGF. Fractions diluted 1:100 were incubated with these cells and mitogenic activity was determined by ${ }^{3} \mathrm{H}$-thymidine incorporation. A representative elution pattern of mitogenic activity for NRK-52E cells is shown in Fig. $2 A(n=8)$. Among the fractions from postischemic kidney, a significant mitogenic ac- tivity was detected in fractions $18-22$, which corresponded to the eluates at 1.0-1.2 M NaCl. From the contralateral kidney, no significant activity was detected in fractions $18-22$. Similar results were obtained in Balb/c3T3 cells $(n=2)$ (Fig. $2 B)$ and RIE-1 cells (not shown). Mitogenic activity was detected in these fractions from the postischemic kidney after various periods of reperfusion. Fig. $2 B$ shows that mitogenic activity for $\mathrm{Balb} / \mathrm{c} 3 \mathrm{~T} 3$ cells was increased in the $1.1 \mathrm{M} \mathrm{NaCl}$ eluates from the 6-, 12-, 24-, and 72-h postischemic kidneys, relative to control samples.

We next examined whether the peak mitogenic fractions (No. 19-21) from postischemic kidneys were capable of inducing EGF-R tyrosine phosphorylation. A431 cells, which overexpress EGF-R, were incubated with eluted fractions, immunoprecipitated with anti-EGF-R antibody, and analyzed by Western blot using antiphosphotyrosine antibody. The $1.1 \mathrm{M}$ $\mathrm{NaCl}$ eluate from the 24-h postischemic kidney was found to induce tyrosine phosphorylation of EGF-R to a level similar to that seen with the addition of exogenous EGF, indicating activation of EGF-R $(n=3)$ (Fig. 3). In contrast, the equivalent fraction from the contralateral kidney did not induce autophosphorylation of EGF-R. In other experiments, EGF-R tyrosine phosphorylation was also increased by the mitogenic fraction of the 6-h postischemic kidney (data not shown).

These peak mitogenic fractions from the 24-h postischemic kidney were further analyzed by Western blot using an antirat HB-EGF polyclonal antibody. As shown in Fig. 4, two bands of apparent molecular mass 29 and $22 \mathrm{kD}$ were detected with this antibody $(n=3)$. The $22-\mathrm{kD}$ protein is of comparable size to secreted human HB-EGF, while the $29-\mathrm{kD}$ protein is of comparable size to the membrane-bound precursor of human HB-EGF (pro-HB-EGF).

Expression of HB-EGF $m R N A$ and histological localization of immunoreactive $H B-E G F$ in acute ischemic renal in-

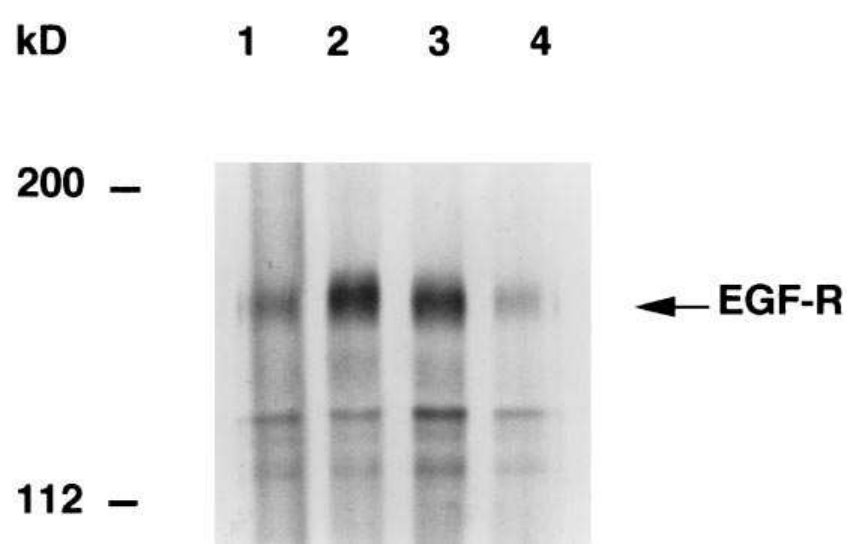

Figure 3. Induction of EGF-R tyrosine phosphorylation by heparinbinding proteins isolated from rat kidney. A431 cells were incubated for $10 \mathrm{~min}$ on ice with either $300 \mathrm{nM}$ EGF or heparin-binding proteins eluted at 1.0-1.2 NaCl from the heparin-TSK FPLC column. Cell lysates were prepared and immunoprecipitated with anti-EGF-R antibody. Immunoprecipitates were subjected to 6\% SDS-polyacrylamide gel electrophoresis and analyzed by Western blot using antiphosphotyrosine antibody as described in Methods. The arrow indicates tyrosine-phosphorylated EGF-R of cells incubated with saline (lane 1), EGF (lane 2), 1.0-1.2 M NaCl eluate fractions from postischemic kidney (lane 3 ), and corresponding eluate fraction from contralateral kidney (lane 4). 
kD

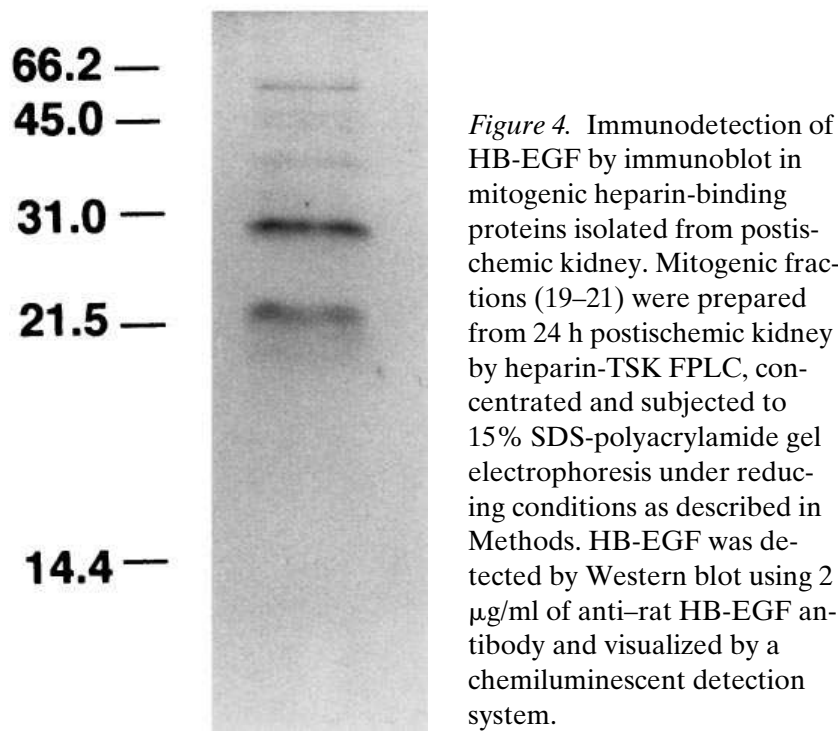

jury. We have previously reported that HB-EGF mRNA expression was increased in kidneys subjected to ischemia/reperfusion injury (31). Expression of HB-EGF mRNA was observed as early as $1 \mathrm{~h}$ after reperfusion and remained elevated at $6 \mathrm{~h}$ of reperfusion. At $6 \mathrm{~h}$ of reperfusion, markedly increased mRNA expression was observed in both cortex and outer medulla, with greater relative increase in outer medulla, while no significant mRNA expression was noted in contralateral kidneys (31). Using immunohistochemical techniques, we have further analyzed the localization of HB-EGF protein. In contralateral kidneys, low levels of HB-EGF immunoreactivity were detected in intralobular arteries and occasional cortical collecting duct cells, but immunoreactivity was absent from the outer and inner stripes of outer medulla (Fig. 5, $A$ and $C$ ). In postischemic kidney, increased immunoreactive HB-EGF was observed in collecting ducts and thick ascending limbs of cortex and outer medulla (Fig. 5, $B$ and $D-F$ ). In agreement with the expression of mRNA, immunoreactive HB-EGF was more abundant in outer medulla than in cortex. Specificity controls using anti-HB-EGF antibody preabsorbed with rHBEGF totally abolished this increased tubular immunoreactivity in the postischemic kidney. It is notable that no increase of immunoreactivity was seen in the straight portion of proximal tubular cells (S3 segment), the site most vulnerable to ischemia/ reperfusion injury $(1,2)$.

Expression of HB-EGF in nephrotoxic acute injury induced by aminoglycoside. To investigate whether HB-EGF is produced in other types of acute renal injury, gentamicin-induced nephropathy was examined. Aminoglycoside is reported to be predominately a proximal tubule toxin, especially for $\mathrm{S} 1$ and S2 segments in cortex (45). Acute renal failure was induced by subcutaneous injection of gentamicin $(400 \mathrm{mg} / \mathrm{kg}$ per d) and was evaluated by measurement of elevations of serum BUN and characteristic histopathological changes. After gentamicin injection, BUN increased by day $4(70.3 \mathrm{mg} / \mathrm{dl}$; control; 19.8 $\mathrm{mg} / \mathrm{dl})$, and reached a peak at day $6(137.5 \mathrm{mg} / \mathrm{dl})$, followed by a gradual return to baseline (Table I). As shown in Fig. 6, ex-
Table I. Blood Urea Nitrogen (BUN) After Induction of Gentamicin Nephrotoxicity

\begin{tabular}{llc}
\hline Day & & $\mathrm{BUN}(\mathrm{mg} / \mathrm{dl})$ \\
\hline Control & $(n=8)$ & $19.8 \pm 1.2$ \\
2 & $(n=4)$ & $31.0 \pm 3.4$ \\
4 & $(n=6)$ & $70.3 \pm 16.1$ \\
6 & $(n=4)$ & $137.5 \pm 38.1$ \\
8 & $(n=3)$ & $98.3 \pm 30.4$ \\
10 & $(n=1)$ & 50 \\
\end{tabular}

Acute renal failure was induced in the rats by subcutaneous injection of gentamicin (400 mg/kg per d) as described in Methods. Blood samples were drawn and urea nitrogen was measured.

pression of HB-EGF mRNA was induced in the kidney and remained elevated at day 8 after induction of the disease. This increase in mRNA expression was observed both in renal cortex and outer medulla. A relatively earlier induction in cortex was observed and reached a peak at day 4 ; in contrast, HBEGF mRNA induction in outer medulla was greatest at day 6 (Fig. 6). In other experiments, rats were treated with $200 \mathrm{mg} /$ $\mathrm{kg}$ per $\mathrm{d}$ of gentamicin. In these animals, BUN level was only $37 \mathrm{mg} / \mathrm{dl}$ at day 6. A 3.2-fold increase of HB-EGF mRNA expression was detected in the kidneys of animals treated with the $200 \mathrm{mg} / \mathrm{kg}$ per $\mathrm{d}$ concentration of gentamicin, whereas a 10.4-fold increase was noted in the kidneys of rats treated with $400 \mathrm{mg} / \mathrm{kg}$ per d of gentamicin (not shown). Histologic analysis indicated severe tubular injury at day 6 in rats treated with 400 $\mathrm{mg} / \mathrm{kg}$ per d of gentamicin, with loss of proximal tubular cellular integrity, cell detachment from the basement membrane, and the presence of necrotic cells and cell debris in the tubular lumen (Fig. 7). Immunoreactive HB-EGF was detected in thick limbs and collecting ducts in cortex and outer medulla, as well as in afferent arteriole smooth muscle. In addition, immunoreactive HB-EGF was detected on the lumenal surface of the distal convoluted tubules. Whether this localization represented local expression of peptide or binding of lumenal HB-EGF released from thick ascending limb could not be determined from these studies. There was no positive immunostaining of infiltrating cells in the interstitium. Minimal histological changes were observed in rats treated with $200 \mathrm{mg} / \mathrm{kg}$ per $\mathrm{d}$ gentamicin and the tubular expression of immunoreactive HB-EGF was much less pronounced (not shown). These observations suggest that the expression of HB-EGF is dependent on the extent of renal tubular injury and that the cells primarily responsible for HB-EGF production are in the collecting tubules and thick ascending limb.

Induction of EGF-R $m R N A$ in acute renal injury. Biological effects of HB-EGF are mediated through EGF-R (30) and increased EGF binding has been shown in postischemic kidney $(16,18)$. We therefore examined whether EGF-R mRNA expression increases in rat kidney after acute renal injury. In postischemic kidney, EGF-R mRNA expression normalized to GAPDH was increased 1.5 -fold at $24 \mathrm{~h}$ and 2.1 -fold at $48 \mathrm{~h}$ after reperfusion compared with contralateral kidney $(n=2)$ (Fig. $8 \mathrm{~A}$ ). Similar results were obtained in the model of gentamicin nephrotoxicity. Increased expression of EGF-R mRNA was observed after disease induction (Fig. $8 B$ ) as early 


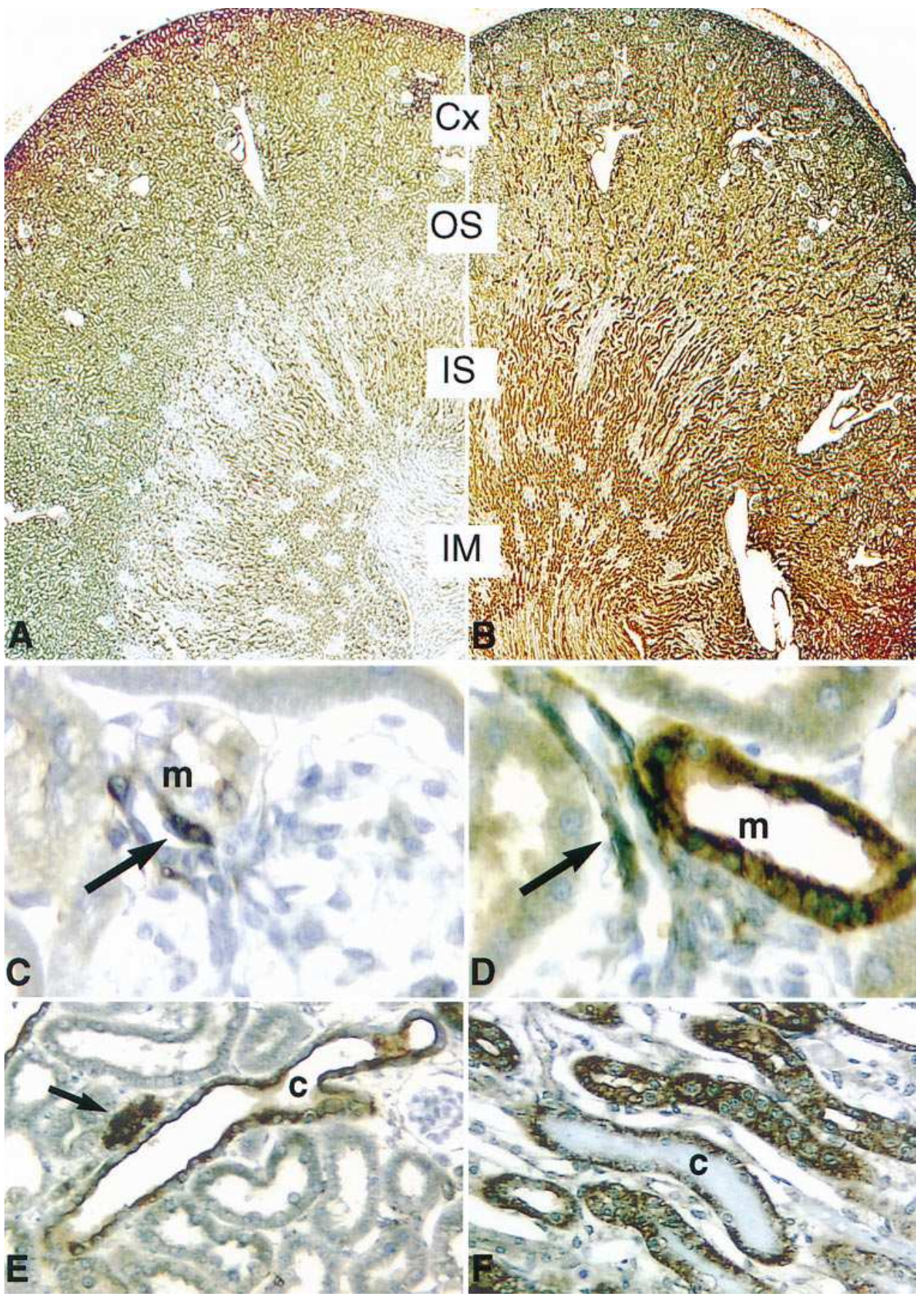

Figure 5. Localization of immunoreactive HB-EGF in postischemic rat kidney. Unilateral renal ischemia was induced by clamping the left renal artery for $50 \mathrm{~min}$. After $24 \mathrm{~h}$ reperfusion, kidneys were fixed with FPAS and stained to localize HB-EGF-ir (brown reaction product) as described in Methods. $\mathrm{Cx}$, cortex; OS, outer stripe; IS, inner stripe; IM, inner medulla. ( $A$ and $C$ ) Nonischemic contralateral kidney. ( $B$ and $D-F$ ) Postischemic kidney showing enhanced levels of HB-EGF-ir in TALH and collecting ducts in cortex and medulla. At higher magnification of the vascular pole of glomeruli $(C$ and $D)$, both kidneys show strong staining in a few cells in the smooth muscle of the afferent arteriole immediately adjacent to the juxtaglomerular apparatus (arrows), but the post-ischemic kidney $(D)$ has enhanced HB-EGF-ir in TALH at the level of the macula densa $(m)$. Cortex of postischemic kidney $(E)$ also shows strong HB-EGF-ir in TALH cells (arrow) and at the surface of the cortical collecting duct $(c)$; intracellular staining is apparent in scattered CCD cells. In the inner stripe $(F)$, intracellular HB-EGF-ir is apparent in both the collecting ducts filled with casts $(c)$ and adjacent thick ascending limbs. $A$ and $B, 16 \times ; C$ and $D, 666 \times ; E$ and $F, 267 \times$ as day 2 and was greatest at day 6. Expression was seen in both cortex and outer medulla (not shown).

HB-EGF immunolocalization in renal development. To investigate further the potential role of HB-EGF in kidney growth, expression and localization of immunoreactive HBEGF in rat embryonic kidney was examined. Expression of HB-EGF was observed as early as embryonic day 14.5. Immunoreactive HB-EGF was detected in ureteric bud. At embryonic day 17.5, strong HB-EGF immunoreactivity was found in derivatives of the ureteric buds including developing medullary and cortical collecting ducts (Fig. $9 A$ ). Immunoreactive HB-EGF was also in cells of the developing thick ascending limb of Henle (TALH) at the glomerular vascular pole (Fig. 9
$B)$. Similar to results in the postischemic kidney, preabsorption controls demonstrated the specificity of epithelial HB-EGF immunoreactivity in embryos. However, the diffuse interstitial staining was not affected, indicating that it represents background staining.

\section{Discussion}

HB-EGF is a member of the EGF superfamily of growth factors that signal through EGF-R tyrosine phosphorylation. HBEGF is expressed in macrophages, $\mathrm{T}$ lymphocytes, vascular smooth muscle cells, endothelial cells (30, 46-49), keratinocytes, and intestinal epithelial cells (39). We have recently re- 

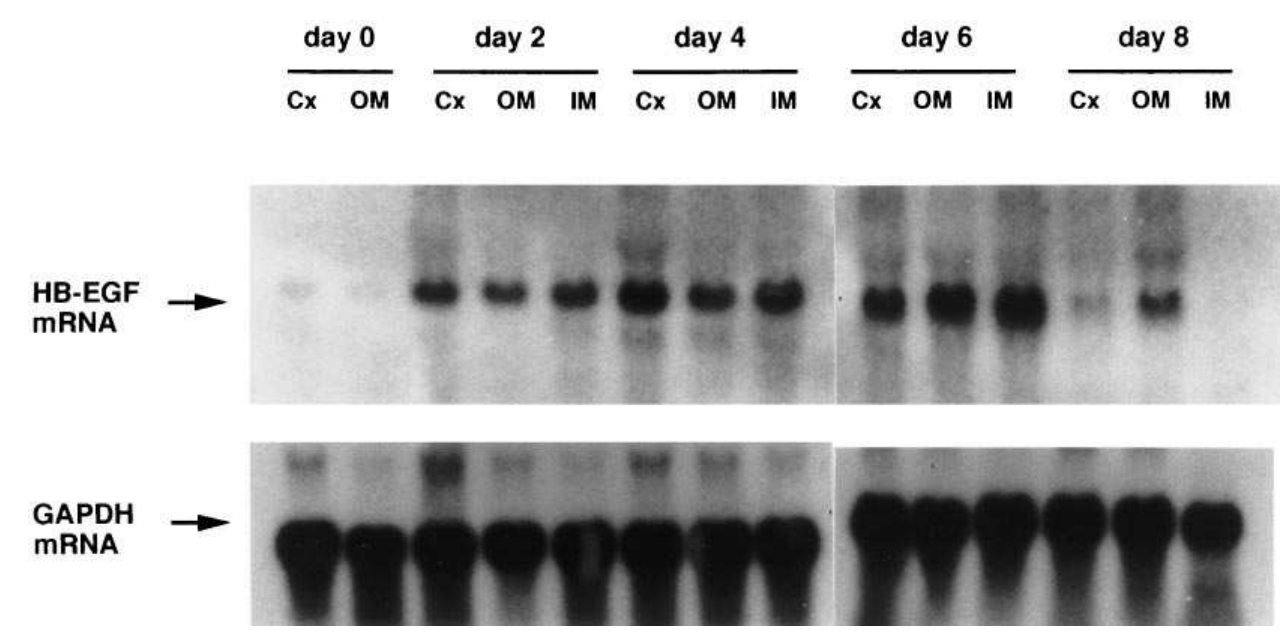

Figure 6. Induction of HB-EGF mRNA in gentamicin-induced nephrotoxicity. Gentamicin nephrotoxicity was induced in rats with $400 \mathrm{mg} / \mathrm{kg}$ per $\mathrm{d}$ of gentamicin, and total RNA was extracted from cortex $(C x)$, outer medulla $(O M)$, and inner medulla $(I M)$ at the indicated times after injection of gentamicin and examined for HB-EGF mRNA expression. ported that HB-EGF mRNA is also inducible in rat kidney in response to acute renal injury (31). In the present studies, we demonstrate that HB-EGF is produced as a bioactive protein in rat kidneys of acute renal failure models and may act as a growth factor during renal regeneration.

Heparin-binding proteins were purified from the homogenates of postischemic kidneys by heparin-affinity column chromatography, and a large peak of proteins was eluted at $1.0-1.2 \mathrm{M}$ $\mathrm{NaCl}$. Similar peaks were detected at 6-72 h after ischemia, whereas no significant peaks were eluted at the same concentration of $\mathrm{NaCl}$ from the contralateral kidneys at each time point. This elution pattern from the homogenates of postischemic kidney was identical to that of conditioned medium of phorbolester-treated U937 cells. U937 cell-derived human HB-EGF has $76 \%$ amino acid sequence homology with rat HB-EGF (47) and is well characterized. It contains an EGFlike domain and a heparin-binding domain and acts as a potent mitogenic factor for smooth muscle cells, fibroblasts, and epithelial cells (30). The heparin-binding proteins purified from rat kidney in our present studies exhibited similar characteristics. These postischemic kidney-derived heparin-binding proteins were characterized by an ability to induce proliferation in Balb/c3T3 cells, NRK-52E cells, or RIE-1 cells, and to stimulate EGF-R tyrosine phosphorylation in A431 cells, indicating that these proteins are produced in a bioactive form and possess EGF-like properties. Furthermore, using an anti-rat HB-EGF polyclonal antibody, we found immunoreactive HB-EGF in the bioactive fractions.

To date, a number of heparin-binding growth factors have been purified by the use of heparin-affinity chromatography. $\mathrm{HGF}$, one of the renotropic factors in renal regeneration (32, 50 ), is an $82-\mathrm{kD}$ heterodimer protein and is eluted with $0.65-$ $0.9 \mathrm{M} \mathrm{NaCl}$ from heparin sepharose columns (51). HGF stimulates the proliferation of epithelial cells and hepatocytes, but not of fibroblasts. Specifically, it is not mitogenic for Balb/c3T3 cells because of the absence of expression of the HGF receptor, c-met. Acidic fibroblast growth factor (FGF) is eluted by heparin-affinity chromatography at 1.1-1.5 M NaCl (52). Acidic FGF is also produced in acute nephrotoxic injured kidney; however, increases in acidic FGF expression are seen in a later phase of tubular regeneration during an apparently postmitotic period (33). The proteins purified in the present study were detected as early as $6 \mathrm{~h}$ after renal ischemia. The capability of inducing EGF-R tyrosine phosphorylation and the im- munoreactivity to anti-rat HB-EGF antibody revealed that the purified proteins are distinguishable from acidic FGF or other heparin-binding growth factors. Of the members of the EGF family of growth factors, amphiregulin (28) and betacellulin (29) are also heparin-binding proteins, while EGF and TGF $\alpha$ are not. Betacellulin is eluted from heparin affinity col-

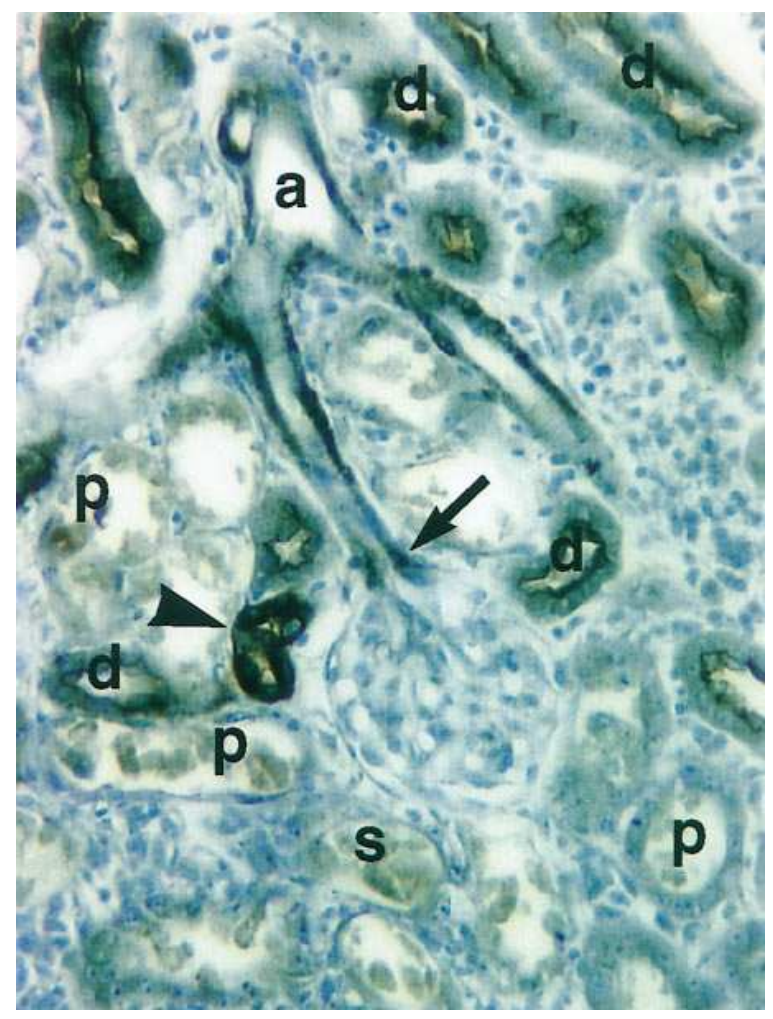

Figure 7. Localization of immunoreactive HB-EGF in gentamicin nephrotoxicity. After treatment with $400 \mathrm{mg} / \mathrm{kg}$ per d gentamicin, cells of the proximal tubules $(p)$ show significant damage. HB-EGF-ir is enhanced in both the TALH (arrowhead) and the afferent arterioles (arrow) identified from their origin at the intralobular artery $(a)$. HB-EGF-ir also is apparent at the lumenal surface of the distal convoluted tubules $(d)$, but not in an intracellular distribution at this locus. $267 \times$. 
A

Time (h)

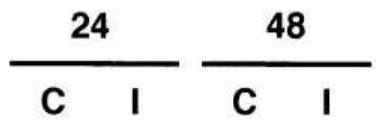

EGF-R MRNA

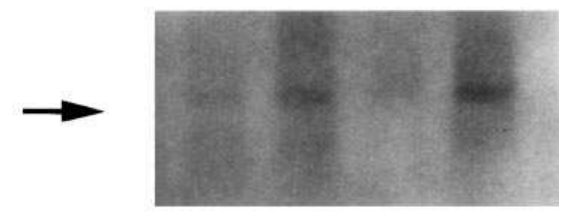

GAPDH
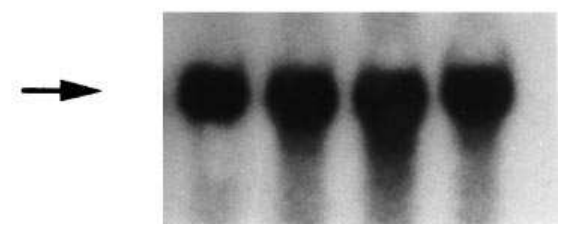

B

\section{Gentamicin $(\mathrm{mg} / \mathrm{kg} /$ day $)$}

$0 \quad 200 \quad 400$

\section{EGF-R MRNA}
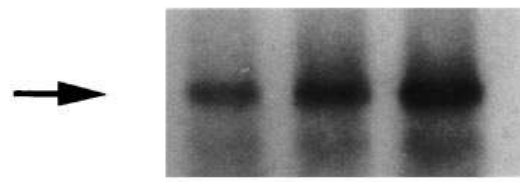

\section{GAPDH mRNA}

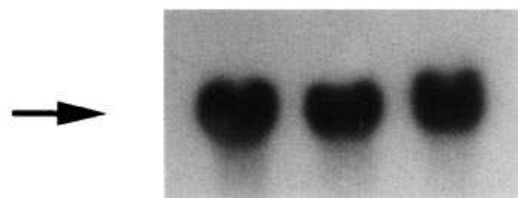

Figure 8. Expression of EGF-R mRNA in rat kidney after acute injury. $(A)$ Total RNA was extracted from postischemic $(I)$ and contralateral $(C)$ kidney at the indicated times of reperfusion and examined for expression of EGF-R mRNA as described in Methods. $(B)$ Total RNA was extracted from rat kidney $6 \mathrm{~d}$ after injection of 200 and $400 \mathrm{mg} / \mathrm{kg}$ per d gentamicin. Expression of EGF-R mRNA was determined as described in Methods.

umn at $<0.3 \mathrm{M} \mathrm{NaCl}$ and amphiregulin is eluted with $1.0 \mathrm{M}$ $\mathrm{NaCl}$, slightly less than the elution point of HB-EGF.

Neither of these growth factors are thought to participate in renal regeneration because their expression is not increased in the injured kidney (31); similarly, expression of TGFo mRNA was not increased in the early phase after ischemic injury (53).

HB-EGF is produced as a membrane-anchored precursor form and processed to the secreted form $(54,55)$. Human HBEGF precursor migrates at $27 \mathrm{kD}$ on SDS-polyacrylamide gel electrophoresis (55), whereas the mature, secreted form of human HB-EGF migrates at $20-22 \mathrm{kD}$. In the present study, Western blot analysis of bioactive eluate fractions showed two bands that were immunoreactive to anti-rat HB-EGF antibody. The protein of $29 \mathrm{kD}$ is larger than the apparent size of human secreted HB-EGF and probably represents the mem- brane-bound precursor of HB-EGF. The smaller band of 22 $\mathrm{kD}$ is of a size consistent with the secreted form of HB-EGF. The precursor of HB-EGF is thought to be enzymatically converted to the secreted form by a protein kinase $\mathrm{C}$-dependent process (56). Therefore, the present results indicate the existence of both membrane bound and soluble HB-EGF in postischemic kidney.

Previous studies have investigated the role of EGF in regeneration after acute renal injury. Exogenous administration of EGF accelerates mitosis and functional recovery of tubular cells after ischemia/reperfusion and nephrotoxic renal injury (9-11). ${ }^{125}$ I-EGF binding activity increases within $24 \mathrm{~h}$ of reperfusion in postischemic kidney $(16,18)$, suggesting an important role of EGF-like growth factors in renal regeneration. However, preproEGF mRNA expression and urinary EGF excretion decrease for up to $7 \mathrm{~d}$ after injury $(16,17)$. In the present study, increased production of bioactive HB-EGF occurred as early as $6 \mathrm{~h}$ after reperfusion, before the onset of mitosis. In addition, our previous studies indicated that recombinant HB-EGF was mitogenic for renal proximal tubular cells and NRK-52E renal epithelial cells (31). Recently, an increase of EGF-R tyrosine phosphorylation has been shown to occur in postischemic kidney observed at $24 \mathrm{~h}$ of reperfusion (57). Taken together, these results suggest that HB-EGF may be involved in the early stage of renal regeneration in acute renal injury.

We also found that expression of EGF-R mRNA was increased during renal regeneration in ischemia/reperfusionand aminoglycoside-induced renal injury concurrently with the increased production of HB-EGF. EGF-R expression is regulated both transcriptionally and posttranscriptionally in vitro. Protein kinase $\mathrm{C}$ stimulates transcription of the EGF-R gene (58), while treatment of cells with EGF also results in increased EGF-R expression, probably due to the posttranscriptional mechanisms (59). In kidneys from gentamicin-treated rats, increased expression of EGF-R mRNA in cortex and outer medulla was noted after $6 \mathrm{~d}$ of disease induction, suggesting that one mechanism by which EGF-R expression increases in the injured kidney may be secondary to induction by HB-EGF.

Immunohistochemical analysis provided further suggestion for involvement of HB-EGF in the renal repair process. HBEGF immunoreactivity was detected in the distal nephron in the areas where injured proximal tubular cells were located. In postischemic kidney, the straight portion of proximal tubules in the outer medulla (S3 segment) is vulnerable to ischemic injury because of the heterogeneous oxygen delivery and generation of reactive oxygen species that occur upon reperfusion (60). However, evidence also suggests the existence of sublethal cell injury in distal tubules in response to ischemia/reperfusion. Clusterin, a marker of the cell injury that is associated with apoptosis, is detected in the postischemic kidney in distal tubules as well as in the straight portion of proximal tubules (6). In addition, distal tubule cells are reported to undergo apoptosis after short periods of ischemia (3-5). In the present study, we showed markedly increased immunostaining for HB-EGF in the postischemic kidneys, which was localized to the collecting ducts and thick ascending limb in cortex and outer medulla, a distribution identical to that of our previous in situ hybridization analysis (31). Since we have demonstrated that HB-EGF is mitogenic for proximal tubule cells with potency equal to that of EGF, production of endogenous HB-EGF by 

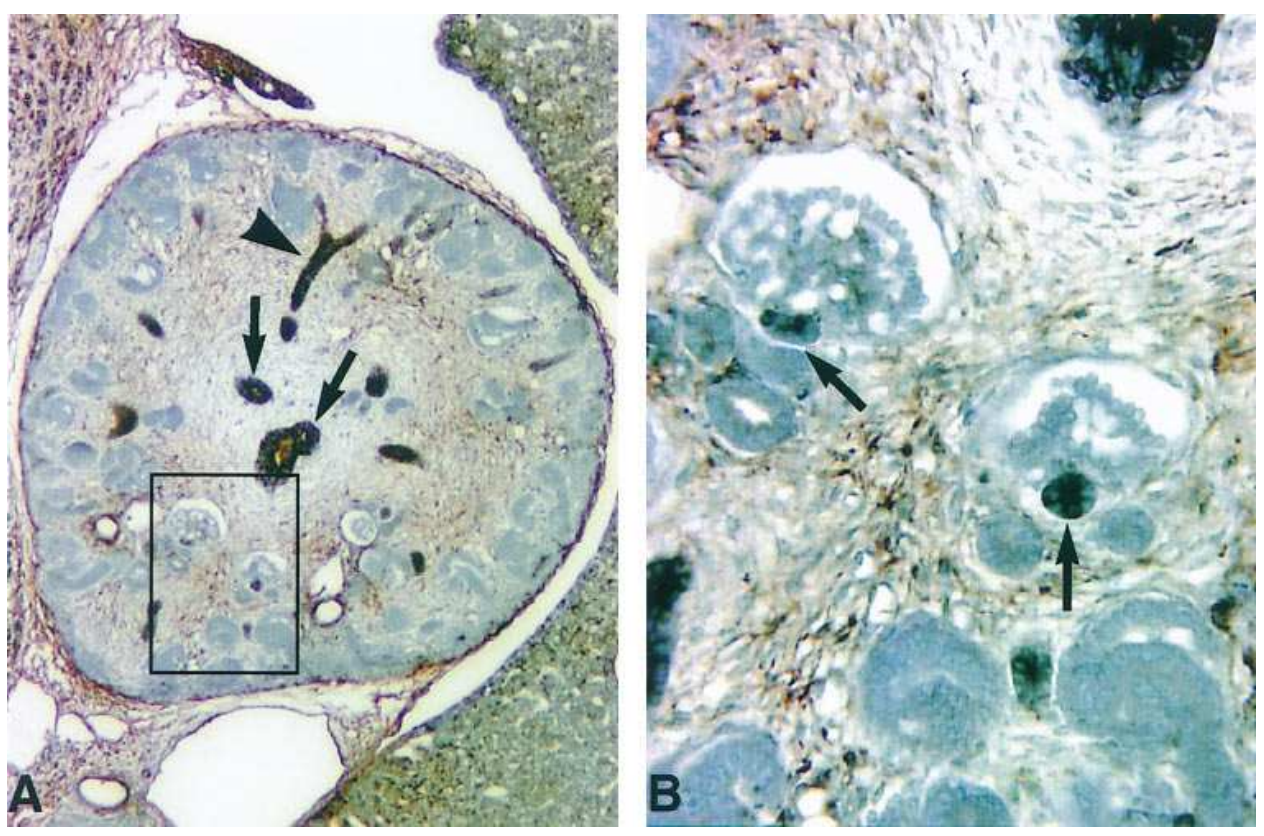

Figure 9. Expression of HB-EGF in rat embryonic kidney. $(A)$ Metanephros of embryonic day 17.5 rat shows strong HB-EGF-ir in derivatives of the ureteric buds including developing medullary collecting ducts (arrows) and branching ducts in the cortex (arrowhead). At higher magnification $(B)$, it is apparent that HB-EGF is strongly present in cells of the nascent TALH at the vascular pole of each glomerulus (arrows). A, $67 \times ; B, 267 \times$.

the distal tubules near the injured proximal tubules suggests a paracrine role in repair and proliferation of proximal tubules in ischemic renal injury.

In the rat model of aminoglycoside nephrotoxicity, the predominant site of injury is the cortical proximal tubules (S1 and $\mathrm{S} 2$ ), which are injured in response to the mitochondrial dysfunction and subsequent generation of reactive oxygen metabolites (61). In the present studies on kidneys from gentamicintreated rats, HB-EGF immunoreactivity present in cortex was localized primarily in distal nephron. Similar to the observations in postischemic kidney, these findings further suggest the distal tubules located close to the injured proximal tubules are also damaged and that these sublethally injured cells may be responsible for local production of HB-EGF, possibly due to reactive oxygen species generated either by the distal tubule cells themselves or by the contiguous proximal tubule cells. This hypothesis is consistent with our previous observations showing an inhibitory effect of antioxidants in induction of HB-EGF mRNA in freshly isolated tubular suspension exposed to anoxia/reoxygenation (31). In preliminary studies, we have also found that expression of HB-EGF in NRK-52E epithelial cells is increased by direct administration of hydrogen peroxide.

During renal regeneration after ischemic injury, increased ${ }^{3} \mathrm{H}$-thymidine incorporation is observed at 24-72 $\mathrm{h}$ after injury, and proliferating cells are localized predominantly to proximal straight tubules, the main target of ischemic injury $(9,14,16)$. Cells labeled with ${ }^{3} \mathrm{H}$-thymidine are also found in the tubules in inner stripe, including thick ascending limb $(6,9)$, a major source of HB-EGF (Fig. 5). Detailed observations of the gentamicin-induced nephrotoxic model by Nouwen et al. (62) have indicated increased immunostaining for proliferating cell nuclear antigen (PCNA) in cortical distal tubules in the early phase of disease, followed by proliferation of cortical proximal tubules. It has also been shown that these cortical distal tubule cells undergo apoptosis in gentamicin-induced nephropathy (62). In light of these observations, our present findings suggest an association between cell injury, HB-EGF production, and turnover of tubule cells. Sublethal injury to distal tubules may cause induction of endogenous HB-EGF, which in turn causes proliferation of proximal tubule cells and repair and/or proliferation of distal tubule cells in a paracrine and autocrine manner, respectively.

Because the response to acute renal injury recapitulates certain aspects of renal development, the study of rat embryonic kidney supports the observations that in adult injured kidney, distal tubules are the major source of HB-EGF. In the present studies, we found significant expression of HB-EGF in ureteric bud as early as E14.5 and in structures derived from the ureteric bud during subsequent embryogenesis. It is of interest that targeted disruption of EGF-R in mice has revealed evidence of abnormalities in differentiation of structures derived from ureteric bud (63), suggesting a possible developmental role for HB-EGF.

In summary, we have demonstrated that HB-EGF is produced as a bioactive protein in response to acute renal injury. This production of HB-EGF is seen earlier than other growth factors described to date and appears to be one of the injury response phenomena. The studies of two different models of acute renal failure provided insight into mechanisms of HBEGF induction, indicating the possibility that sublethally injured distal tubules are the major source of this growth factor. Since HB-EGF was also detected in ureteric bud in rat metanephric kidney, these results suggest that HB-EGF produced by distal tubules may be important for regeneration and differentiation after acute injury.

\section{Acknowledgments}

We thank Dr. Jorge Capdevila of Vanderbilt University for the use of his FPLC system and for helpful suggestions in protein purification.

This work was supported by the National Institutes of Health grants DK-39261 and DK-51265, funds from the Department of Veterans Affairs, and a Tennessee Affiliate American Heart Association fellowship (M. Sakai). Dr. Harris is a Clinical Investigator in the Career Development Program of the Veterans Administration. 


\section{References}

1. Bonventre, J.V. 1993. Mechanisms of ischemic acute renal failure. Kidney Int. 43:1160-1178.

2. Toback, F.G. 1992. Regeneration after acute tubular necrosis. Kidney Int. 41:226-246.

3. Gobe, C.G., R. Buttyan, K.R.L. Wyburn, M.R. Etheridge, and P.J. Smith. 1995. Clusterin expression and apoptosis in tissue remodeling associated with renal regeneration. Kidney Int. 47:411-420.

4. Schumer, M., M.C. Colombel, I.S. Sawczuk, G. Gobe, J. Connor, K.M. O'Toole, C.A. Olsson, G.J. Wise, and R. Buttyan. 1992. Morphologic, biochemical and molecular evidence of apoptosis during the reperfusion phase after brief periods of renal ischemia. Am. J. Pathol. 140:831-838.

5. Beeri, R., Z. Symon, M. Brezis, S.A. Ben-Sasson, P.H. Baehr, S. Rosen, and R.A. Zager. 1995. Rapid DNA fragmentation from hypoxia along the thick ascending limb of rat kidneys. Kidney Int. 47:1806-1810.

6. Witzgall, R., D. Brown, C. Schwarz, and J.V. Bonventre. 1994. Localization of proliferating cell nuclear antigen, vimentin, c-Fos, and clusterin in the post-ischemic kidney. J. Clin. Invest. 93:2175-2188.

7. Racusen, L.C. 1994. Alteration in human proximal tubule cell attachment in response to hypoxia: role of microfilaments. J. Lab. Clin. Med. 123:357-364.

8. Walker, P.D. 1994. Alteration in renal tubular extracellular matrix components after ischemia-reperfusion injury to the kidney. Lab. Invest. 70:339346

9. Humes, H.D., D.A. Cieslinski, T.M. Coimbra, J.M. Messana, and C. Galvao. 1989. Epidermal growth factor enhances renal tubule cell regeneration and repair and accelerates the recovery of renal function in postischemic acute renal failure. J. Clin. Invest. 84:1757-1761.

10. Coimbra, T.M., D.A. Cieslinski, and H.D. Humes. 1990. Epidermal growth factor accelerates renal repair in mercuric chloride nephrotoxicity. Am. J. Physiol. 259:F438-F443.

11. Morin, N.J., G. Laurent, D. Nonclercq, G. Toubeau, J.-A. Heuson-Stiennon, M.G. Bergeron, and D. Beauchamp. 1992. Epidermal growth factor accelerates renal tissue repair in a model of gentamicin nephrotoxicity in rats. Am. J. Physiol. 263:F806-F811.

12. Miller, S.B., D.R. Martin, J. Kissane, and M.R. Hammerman. 1994. Hepatocyte growth factor accelerates recovery from acute ischemic renal injury in rats. Am. J. Physiol. 266:F129-F134.

13. Miller, S.B., D.R. Martin, J. Kissane, and M.R. Hammerman. 1992. Insulin-like growth factor I accelerates recovery from ischemic acute tubular necrosis in the rat. Proc. Natl. Acad. Sci. USA. 89:11876-11880.

14. Norman, J., Y.-K. Tasu, A. Bacay, and L.G. Fine. 1990. Epidermal growth factor accelerates functional recovery from ischaemic acute tubular necrosis in the rat: role of the epidermal growth factor receptor. Clin. Sci. 78:445450 .

15. Rall, L.B., J. Scott, and G.I. Bell. 1985. Mouse prepro-epidermal growth factor synthesis by the kidney and other tissues. Nature (Lond.). 313:228-231.

16. Safirstein, R., P.M. Price, S.J. Saggi, and R.C. Harris. 1990. Changes in gene expression after temporary renal ischemia. Kidney Int. 37:1515-1521.

17. Safirstein, R., A.Z. Zelent, and P.M. Price. 1989. Reduced renal preproepidermal growth factor mRNA and decreased EGF excretion in acute renal failure. Kidney Int. 36:810-815.

18. Behrens, M.T., A.L. Corbin, and M.K. Hise. 1989. Epidermal growth factor receptor regulation in rat kidney: two models of renal growth. Am. J. Physiol. 257:F1059-F1064.

19. Hammerman, M.R., S.A. Rogers, and G. Ryan. 1992. Growth factors and metanephrogenesis. Am. J. Physiol. 262:F523-F532.

20. Goodyer, P.R., J. Fata, C.G. Goodyer, and H. Guyda. 1991. Transforming growth factor-alpha and the ontogeny of epidermal growth factor receptors in rat kidney. Growth Regul. 1:105-109.

21. Taub, M., Y. Wang, T.M. Szczesny, and H.K. Kleinman. 1990. Epidermal growth factor or transforming growth factor $\alpha$ is required for kidney tubulogenesis in matrigel cultures in serum-free medium. Proc. Natl. Acad. Sci. USA. 87:4002-4004.

22. Cybulsky, A.V., P.R. Goodyer, and A.J. McTavish. 1994. Epidermal growth factor receptor activation in developing rat kidney. Am. J. Physiol. 267: F428-F436.

23. Salido, E.C., J. Lakshmanan, L.J. Shapiro, D.A. Fisher, and L. Barajas. 1990. Expression of epidermal growth factor in the kidney and submandibular gland during mouse postnatal development. An immunocytochemical and in situ hybridization study. Differentiation. 45:38-43.

24. Mann, G.B., K.J. Fowler, A. Gabriel, E.C. Nice, R.L. Williams, and A.R. Dunn. 1993. Mice with a null mutation of the TGF $\alpha$ gene have abnormal skin architecture, wavy hair, and curly whiskers and often develop corneal inflammation. Cell. 73:249-261.

25. Luetteke, N.C., T.H. Qui, R.L. Peiffer, P. Oliver, O. Smithies, and D.C. Lee. 1993. TGF $\alpha$ deficiency results in hair follicle and eye abnormalities in targeted and waved-1 mice. Cell. 73:263-278.

26. Brown, P.I., R. Lam, J. Lakshmanan, and D.A. Fisher. 1990. Transforming growth factor alpha in developing rats. Am J. Physiol. 259:F256-F260.

27. Massague, J. 1990. Transforming growth factor- $\alpha$. J. Biol. Chem. 265: 21393-21396.
28. Shoyab, M., G.D. Plowman, V.L. McDonald, J.G. Bradley, and G.J. Todaro. 1989. Structure and function of human amphiregulin: a member of the epidermal growth factor family. Science (Wash. DC). 243:1074-1076.

29. Shing, Y., G. Christofori, D. Hanahan, Y. Ono, R. Sasada, K. Igarashi, and J. Folkman. 1993. Betacellulin: a mitogen from pancreatic $\beta$ cell tumor. Science (Wash. DC). 259:1604-1607.

30. Higashiyama, H., J.A. Abraham, J. Miller, J.C. Fiddes, and M. Klagsbrun. 1991. A heparin-binding growth factor secreted by macrophage-like cells that is related to EGF. Science (Wash. DC). 251:936-939.

31. Homma, T., M. Sakai, H.-F. Cheng, T. Yasuda, R.J. Coffey, and R.C. Harris. 1995. Induction of heparin-binding epidermal growth factor-like growth factor mRNA in rat kidney after acute injury. J. Clin. Invest. 96:1018-1025.

32. Igawa, T., K. Matsumoto, S. Kanda, Y. Saito, and T. Nakamura. 1993. Hepatocyte growth factor may function as a renotropic factor for regeneration in rats with acute renal injury. Am. J. Physiol. 265:F61-F69.

33. Zhang, G., T. Ichimura, J.A.M. Maier, T. Maciag, and J.L. Stevens 1993. A role of fibroblast growth factor type-I in nephrogenic repair. J. Biol. Chem. 268:11542-11547.

34. Matejka, G.L., and E. Jennische. 1992. IGF-I binding and IGF-I mRNA expression in the post-ischemic regenerating rat kidney. Kidney Int. 42:1113 1123

35. McKanna, J.A., A. Chuncharunee, K.A. Munger, J.A. Breyer, S. Cohen, and R.C. Harris. 1992. Localization of p35 (Annexin I, Lipocortin I) in normal adult rat kidney and during recovery from ischemia. J. Cell Physiol. 153:467476.

36. Verstrepen, W.A., E.J. Nouwen, X.S. Yue, and M.E. De Broe. 1993. Altered growth factor expression during toxic proximal tubular necrosis and regeneration. Kidney Int. 43:1267-1279.

37. Blay, J., and K.D. Brown. 1984. Characterization of an epithelioid cell line derived from rat small intestine: demonstration of cytokeratin filaments. Cell Biol. Int. Rep. 8:551-560.

38. De Larco, J.E., and G.J. Todaro. 1978. Epithelioid and fibroblastic rat kidney cell clones: epidermal grown factor (EGF) receptors and the effect of mouse sarcoma virus transformation. J. Cell Physiol. 94:335-342.

39. Barnard, J.A., R. Graves-Deal, M.R. Pittelkow, R. Dubois, P. Cook G.W. Ramsey, P.R. Bishop, L. Damstrup, and R.J. Coffey. 1994. Auto- and cross-induction within the mammalian epidermal growth factor-related peptide family. J. Biol. Chem. 269:22817-22822.

40. Haigler, H., J.F. Ash, S.J. Singer, and S. Cohen. 1978. Visualization by fluorescence of the binding and internalization of epidermal growth factor in human carcinoma cells A-431. Proc. Natl. Acad. Sci. USA. 75:3317-3321.

41. Harris, R.C., and T.O. Daniel. 1989. Epidermal growth factor binding, stimulation of phosphorylation and inhibition of gluconeogenesis in rat proximal tubule. J. Cell Physiol. 139:383-391.

42. McCarthy, S.A., M.L. Samuels, C.A. Pritchard, J.A. Abraham, and M. McMahon. 1995. Rapid induction of heparin-binding epidermal growth factor/ diphtheria toxin receptor expression by Raf and Ras oncogenes. Gene Dev. 9 : 1953-1964.

43. Chomczynski, P., and N. Sacchi. 1987. Single-step method of RNA isolation by acid guanidinium thiocyanate-phenol-chloroform extraction. Anal. Biochem. 162:156-159.

44. Akai, Y., T. Homma, K.D. Burns, T. Yasuda, K.F. Badr, and R.C. Harris. 1994. Mechanical stretch/relaxation of cultured rat mesangial cells induces protooncogenes and cyclooxygenase. Am. J. Physiol. 267:C482-C490.

45. De Broe, M.E., G.J. Paulus, G.A. Verpooten, F. Roels, N. Buyssens, R. Wedeen, F. Van Hoof, and P.M. Tulkens. 1984. Early effects of gentamicin, tobramycin, and amikacin on the human kidney. Kidney Int. 25:643-652.

46. Blotnick, S., G.E. Peoples, M.R. Freeman, T.J. Eberlein, and M. Klagsbrun. 1994. T lymphocytes synthesize and export heparin-binding epidermal growth factor-like growth factor and basic fibroblast growth factor, mitogens for vascular cells and fibroblasts: differential production and release by $\mathrm{CD} 4^{+}$ and CD8 ${ }^{+}$T cells. Proc. Natl. Acad. Sci. USA. 91:2890-2894.

47. Temizer, D.H., M. Yoshizumi, A. Perrella, E.E. Susanni, T. Quertermous, and M.-E. Lee. 1992. Induction of heparin-binding epidermal growth factor-like growth factor mRNA by phorbol ester and angiotensin II in rat aortic smooth muscle cells. J. Biol. Chem. 267:24892-24896.

48. Dulz, S.M., S. Higashiyama, D. Damm, J.A. Abraham, and M. Klagsbrun. 1993. Heparin-binding epidermal growth factor-like growth factor expression in cultured fetal human vascular smooth muscle cells. J. Biol. Chem. 268 18330-18334.

49. Yoshizumi, M., S. Kourembanas, D.H. Temizer, R.C. Cambria, T. Quertermous, and M.-E. Lee. 1992. Tumor necrosis factor increases transcription of the heparin-binding epidermal growth factor-like growth factor gene in vascular endothelial cells. J. Biol. Chem. 267:9467-9469.

50. Nagaike, M., S. Hirao, H. Tajima, S. Sumihare, S. Taniguchi, K. Matsumoto, and T. Nakamura. 1991. Renotropic functions of hepatocyte growth factor in renal regeneration after unilateral nephrectomy. J. Biol. Chem. 266: 22781-22784.

51. Matsumoto, A., and N. Yamamoto. 1991. Sequestration of a hepatocyte growth factor in extracellular matrix in normal adult rat liver. Biochem. Biophys. Res. Commun. 174:90-95.

52. Gospodarowicz, D., J. Cheng, G.-M. Lui, A. Baird, and P. Bohlent. 
1984. Isolation of brain fibroblast growth factor by heparin-Sepharose affinity chromatography: identity with pituitary fibroblast growth factor. Proc. Natl. Acad. Sci. USA. 81:6963-6967.

53. Humes, H.D., and T.O. Daniel. 1990. Proto-oncogene and growth factor gene expression during the repair phase of ischemic acute renal failure. J. Am. Soc. Nephrol. 37:484. (Abstr.)

54. Higashiyama, S., K. Lau, G.E. Besner, J.A. Abraham, and M. Klagsbrun. 1992. Structure of heparin-binding EGF-like growth factor. J. Biol. Chem. 267:6205-6212.

55. Ono, M., G. Raab, K. Lau, J.A. Abraham, and M. Klagsbrun. 1994. Purification and characterization of transmembrane forms of heparin-binding EGF-like growth factor. J. Biol. Chem. 269:31316-31321.

56. Raab, G., S. Higashiyama, S. Hetelekidis, J.A. Abraham, D. Damm, M. Ono, and M. Klagsbrun. 1994. Biosynthesis and processing by phorbol ester of the cell surface-associated precursor form of heparin-binding EGF-like growth factor. Biochem. Biophys. Res. Commun. 204:592-597.

57. Lin, J.-J., A.V. Cybulsky, P.R. Goodyer, R.N. Fine, and F.J. Kaskel. 1995. Insulin-like growth factor-1 enhances epidermal growth factor receptor activation and renal tubular cell regeneration in post-ischemic acute renal failure. J. Lab. Clin. Med. 125:724-733.
58. Johnson, A.C. 1996. Activation of epidermal growth factor receptor gene transcription by phorbol 12-myristate 13-acetate is mediated by activator protein 2. J. Biol. Chem. 271:3033-3038.

59. Clark, A.J.L., S. Ishii, N. Richert, G.T. Merlino, and I. Pastan. 1985. Epidermal growth factor regulates the expression of its own receptor. Proc. Natl. Acad. Sci. USA. 82:8374-8378.

60. Hellberg, P.O.A., Ö. Källskog, and M. Wogast. 1991. Red cell trapping and post-ischemic renal blood flow. Difference between the cortex, outer and inner medulla. Kidney Int. 40:625-631.

61. Walker, P.D., and S.V. Shah. 1987. Gentamicin enhanced production of hydrogen peroxide by renal cortical mitochondria. Am. J. Physiol. 253:C495C499.

62. Nouwen, E.J., W.A. Verstrepen, N. Buyssens, M.-Q. Zhu, and M.E. De Broe. 1994. Hyperplasia, hypertrophy, and phenotypic alteration in the distal nephron after acute proximal tubular injury in the rat. Lab. Invest. 70:479-493.

63. Threadgill, D.W., A.A. Dlugosz, L. Hansen, T. Tennenbaum, U. Lichi, D. Yee, C. LeMantia, T. Mourton, K. Herrup, R.C. Harris, et al. 1995. Targeted disruption of mouse EGF-receptor: evidence that genetic background affects mutant phenotype. Science (Wash. DC). 269:230-234. 